\title{
THE EFFECT OF PROCEDURAL JUSTICE AND BIG FIVE PERSONALITY ON ORGANIZATIONAL CITIZENSHIP BEHAVIOUR THROUGH ORGANIZATIONAL COMMITMENT OF EMPLOYEES AT KUTAI KARTANEGARA TENGGARONG UNIVERSITY
}

\author{
Palinggi Yonathan ${ }^{\star}$, Mawardi, Susandy \\ Kutai Kartanegara University, Indonesia \\ `E-mail: mawardi@unikarta.ac.id
}

\begin{abstract}
This study aims to analyze the influence of Procedural Justice, Big Five Personality, and Organizational Commitment on Organizational Citizenship Behavior on employees of Kutai Kartanegara University, Tenggarong. The analytical tool used was structural equation modeling. The samples used in this study were 92 respondents. The results showed that Procedural Justice had a significant effect on Organizational Citizenship Behavior; the second finding is that the Big Five Personality at Kutai Kartanegara University had a significant effect on Organizational Commitment. The third finding is that the Organizational Commitment of employees at Kutai Kartanegara University had a significant effect on Organizational Citizenship Behavior. And the fourth finding is Big Five Personality of employees at Kutai Kartanegara University had a significant effect on employees' Organizational Citizenship Behavior.
\end{abstract}

\section{KEY WORDS}

Procedural justice, big five personality, organizational commitment, organizational citizenship behavior.

Organizational Citizenship Behavior is an extra individual behavior, which is not directly or explicitly recognizable in a formal work system, and aggregately can increase the effectiveness of Organizational functions (Organ, 2006). Organizations generally believe that to achieve superiority an individual must strive for the highest performance, because basically individual performance affects the performance of a team or work group and ultimately affects the whole organizational performance.

Kutai Kartanegara University (UNIKARTA) is one of the Private Universities in the East Kalimantan Region that was established since May 26, 1984. The phenomenon of extra-role behavior that occurs in employees of the Kutai Kartanegara University in Tenggarong based on observations and literature surveys, researchers see that conditions of this extra-role occurs only to a few employees. It is known that if there are some people or certain divisions that have completed their work, they are still willing to provide assistance to other people or divisions who are still working. Then, there are also employees who are willing to replace the shifts of colleagues who have to leave the workplace because there are matters that cannot be neglected while continuing to complete their duties. Organizational Citizenship Behavior that is expected to occur in all employees of Kutai Kartanegara University is still not optimal and comprehensive. The fact that many employees are reluctant to engage in extra-role behavior is not only due to individual character, but it occurs because there are other aspects such as inadequate Standard Operating Procedures (SOP) as well as unclear application of Standard Operating Procedures (SOP) that have been set.

Leaders are the central of figure for their employees, leaders who are able to create an ideal work environment can trigger extra-role behavior or Organizational Citizenship Behavior. In this case, this is a fact that there are still leaders in the Faculties, bureaus and institutions in Kutai Kartanegara University that have not been able to create the ideal work environment. The interpersonal conflicts of employees that are not able to be handled properly by the leaders and the employees themselves also influence the weak initiation to carry out this extra-role behavior. 
The lack of Organizational Citizenship Behavior practices at Kutai Kartanegara University based on the results of observations and survey of literature caused by Procedural Justice. Procedural Justice by Henle (2005) is defined as employee perceptions about fairness in the workplace and describing an explanation based on the situation of internal irregularities in the workplace. From some of the aspects mentioned above, based on the results of observations and surveys of the Organizational Commitment literature also influence the lack of practice of Organizational Citizenship Behavior at the University of Kutai Kartanegara. Organizational Commitment is employee attachment to the organization where the employee works, where the attachment is intended both in emotional and rational attachment, both for the advantages and disadvantages of working in the organization and about the survival and career gained in working at the organization (Allen \& Meyer, 1990).

This research was conducted to find out about how the characteristics of the Organizational Citizenship Behavior of 92 employees of Kutai Kartanegara University as respondents included 7 Faculties, 1 postgraduate degree, 3 Bureaus, and several existing internal institutions. In this case, the results of the study are expected to be used as a benchmark for leaders in making institutional decisions from various leadership elements so that improvements can be made or guidance in efforts to improve employees' performance and can provide excellent service optimally in accordance with the needs of students and lecturers, so that the positive image of Organizational Citizenship Behavior can be seen through several other related aspects such as; Procedural Justice, Big Five Personality, and Organizational Commitment.

The concept of Organizational Citizenship Behavior was first discussed in the organizational research literature in the early 1980s (Bateman and Organ, 1983; Smith et al., 1983; in Bienstock et al. (2003: 360), Robbins (2006) in Salwa, Wikansari (2017) argues that Organizational Citizenship Behavior is an optional behavior that is not part of an employee's formal work obligations, but effectively supports the functioning of the organization.

Organizational Citizenship Behavior is an optional behavior that is not part of an employee's formal work obligations, but supports the functioning of the organization effectively Bateman and Organ (1983), Smith et al. (1983), in Bienstock et al. (2003: 360).

Based on the definition above, it can be concluded that the Organizational Citizenship Behavior is a positive work behavior that is not a formal work obligation imposed by the organization, but is effective in increasing work productivity. The organizational indicators of the Citizenship Behavior used in this study are the opinions of (Organ, 2006: 298) in Salwa, Wikansari (2017), namely altruism, courtesy, sportsmanship, civic virtue, and peacemaking.

$\mathrm{H1}$ : Procedural Justice has an influence on Organizational Citizenship Behavior. The better implementation of Procedural Justice will improve Organizational Citizenship Behavior.

Procedural Justice is part of Organizational Justice which has a definition as the employee's perception of fairness in the workplace and illustrates the explanation based on the situation of workplace irregularities (Henle, 2005). Furthermore, the results of a review of the literature states that Procedural Justice has an influence on Organizational Citizenship Behavior, this was stated by Greenberg (2005) in Wikantari (2014) that people will be concerned with other people towards the organization where they work when they believe that the organization has treated them fairly.

Greenberg revealed that if an organization is fair to all its members in terms of the distribution of results and organizational resources and policies that are generally and proportionally applied, then the tendency of employees to be individual will be minimized because each individual would expect justice in the work environment. This will motivate members of the organization to focus more on organizational goals that must be achieved together with mutual assistance (altruism). Henceforth in Leventhal's opinion in Gilliland (2003) in Wikantari (2014), the dimensions of Procedural Justice can be measured by six indicators: Consistency, Bias Suppression Accuracy Correct ability, Ethicality, Representativeness.

Based on the results of theoretical studies that have been accumulated, so the hypotheses that can be submitted are as follows. 
H2: Big Five Personality has an influence on Organizational Commitment.

Big Five Personality according to Costa and Mc Crae in Mauna and Shabur (2017), human personality consists of five factors and humans tend to have one personality factor as a dominant factor. Based on this definition it can be seen that the Big Five Personality is a set of characteristics, tendencies and temperaments that are relatively stable that affect the actions and interactions of individuals in responding to something that is faced, as well as an identity that distinguishes one individual from another individual. From the results of the literature review above, it is stated that Big Five Personality influences Organizational Commitment, this is as stated by Goldberg, Feist (2009) in Mauna and Shabur (2017).

Furthermore Costa \& McCrae, Ivancevich (2006: 95) in Mauna and Shabur (2017) to understand the behavior of big five personality, it can be measured from extraversion, emotional stability, openness to experience, agreeableness and conscientiousness.

H3: Organizational Commitment has an influence on Organizational Citizenship Behavior. The higher Organizational Commitment, it will increase Organizational Citizenship Behavior.

Organizational Commitment according to Greenberg \& Baron (2003: 160) in Mauna and Shabur (2017) is the degree to which employees are involved in the organization and wish to remain as the member of organization, which contains loyalty and willingness of employees to work optimally for the organization where the employee works. Furthermore, the company's success can be achieved, so it is necessary to have organizational commitment and high job satisfaction to be given to employees so that employees not only work in accordance with the job description but also carry out activities outside the employee's job description (extra-role) or can be called as Organizational Citizenship, Sena Behavior (2011) Mauna and Shabur (2017).

Meanwhile, according to Steers \& Porter (1983: 442) in Mauna and Shabur (2017) Organizational Commitment is an attitude in which individuals identify themselves with the goals and expectations of the organization where they work and try to maintain membership in the organization to realize the goals of the organization. Organizational Commitment has an important role in improving employee Organizational Citizenship Behavior. According to Meyer \& Allen (1984) in Mauna and Shabur (2017) Organizational Commitment is a sense of employee attachment to a strong organization and can be measured by Affective Commitment, Continuance Commitment, and Normative Commitment.

$\mathrm{H} 4$ : There is an indirect relationship between Big Five Personality on Organizational Citizenship Behavior through Organizational Commitment.

\section{METHODS OF RESEARCH}

The population in this study was employees of the University of Kutai Kartanegara especially the employees who are in the middle and bottom management position, with a total of 120 respondents. The method used in this sampling uses the Slovin formula with a significance level of $5 \%$ and produced a sample of 92 respondents.

\section{RESULTS AND DISCUSSION}

Convergent Validity is measuring the validity of reflexive indicators as a measure of variables that can be seen from the outer loading of each indicator variable. Reflective size is said to be high if it correlates more than 0.60 with the construct that is to be measured. However, for the initial stage of research the development of a measurement scale of 0.5 loading value is considered sufficient (Chin, 1998 in Ghozali, 2006).

Discriminant Validity indicator can be seen in the cross-loading between the indicator and its latent variable. If the correlation of latent variables with indicators is greater than the size of other latent variables, then it shows that the latent construct predicts the size of their block better than the size of other blocks (Ghozali, 2008). 
Table 1 - Cross Loading Values in Discriminant Validity

\begin{tabular}{ccccc}
\hline \hline $\mathrm{n} / \mathrm{n}$ & $\begin{array}{c}\text { Organizational } \\
\text { Commitment }(\mathrm{Y} 1)\end{array}$ & $\begin{array}{c}\text { Big Five Personality } \\
(\mathrm{X} 1)\end{array}$ & $\begin{array}{c}\text { Organizational Citizenship } \\
\text { Behavior (Y2) }\end{array}$ & $\begin{array}{c}\text { Procedural Justice } \\
(\mathrm{X} 2)\end{array}$ \\
\hline \hline OC1 & 0,733 & & & \\
OC2 & 0,757 & & & \\
OC3 & 0,819 & 0,355 & & \\
BF1 & & 0,771 & & \\
BF2 & & 0,543 & & \\
BF3 & & 0,665 & & \\
BF4 & & 0,693 & & 0,699 \\
BF5 & & & & 0,756 \\
PJ1 & & & & 0,886 \\
PJ2 & & & & 0,070 \\
PJ3 & & & & 0,403 \\
PJ4 & & & 0,728 & \\
PJ5 & & & 0,514 & \\
PJ6 & & & 0,599 & \\
OC1 & & & 0,756 & \\
OC2 & & & & \\
OC3 & & & & \\
OC4 & & & & \\
OC5 & & & & \\
\hline
\end{tabular}

Source: PLS Output, 2019.

Based on the loadings value table above, the indicators BF1, PJ3, PJ5, and PJ6 must be removed from the model because they have loadings value less than 0.5 and they are not significant.

After evaluating the first stage of discriminant validity by issuing a drop indicator that has a loading factor value below 0.5 , it is necessary to retest, to make sure each indicator has a loading factor value above 0.5 . are obtained:

Based on the estimation results of discriminant validity phase II, the following values

Table 2 - Cross Loading Values in Discriminant Validity Phase II

\begin{tabular}{|c|c|c|c|c|}
\hline & Big Five Personality (X1) & $\begin{array}{c}\text { Organizational Citizenship } \\
\text { Behavior (Y2) }\end{array}$ & $\begin{array}{c}\text { Organizational } \\
\text { Commitment (Y1) }\end{array}$ & $\begin{array}{c}\text { Procedural } \\
\text { Justice (X2) }\end{array}$ \\
\hline X1.2 & 0.807 & & & \\
\hline X1.3 & 0.523 & & & \\
\hline 11.4 & 0.755 & & & \\
\hline X1.5 & 0.681 & & & 0.758 \\
\hline X2.1 & & & & 0.773 \\
\hline X2.2 & & & 0.733 & \\
\hline X2.4 & & & 0.756 & \\
\hline Y1.1 & & & 0.821 & \\
\hline Y1.2 & & & & \\
\hline Y1.3 & Y2.1 & 0.708 & & \\
\hline Y2.2 & & 0.511 & & \\
\hline Y2.3 & & 0.566 & & \\
\hline Y2.4 & & 0.790 & & \\
\hline Y2.5 & & 0.623 & & \\
\hline
\end{tabular}

Source: PLS Output, 2019.

Testing the structural model or the Inner Model is done by looking at the R-square value which is a model of goodness-fit test.

The relationship of Big Five Personality to Organizational Commitment has an RSquare value of 0.170 , which means that the Organizational Commitment variable that can be explained by Big Five Personality is only $17 \%$. The rest $83 \%$ is influenced by other variables which are not examined in this study. 


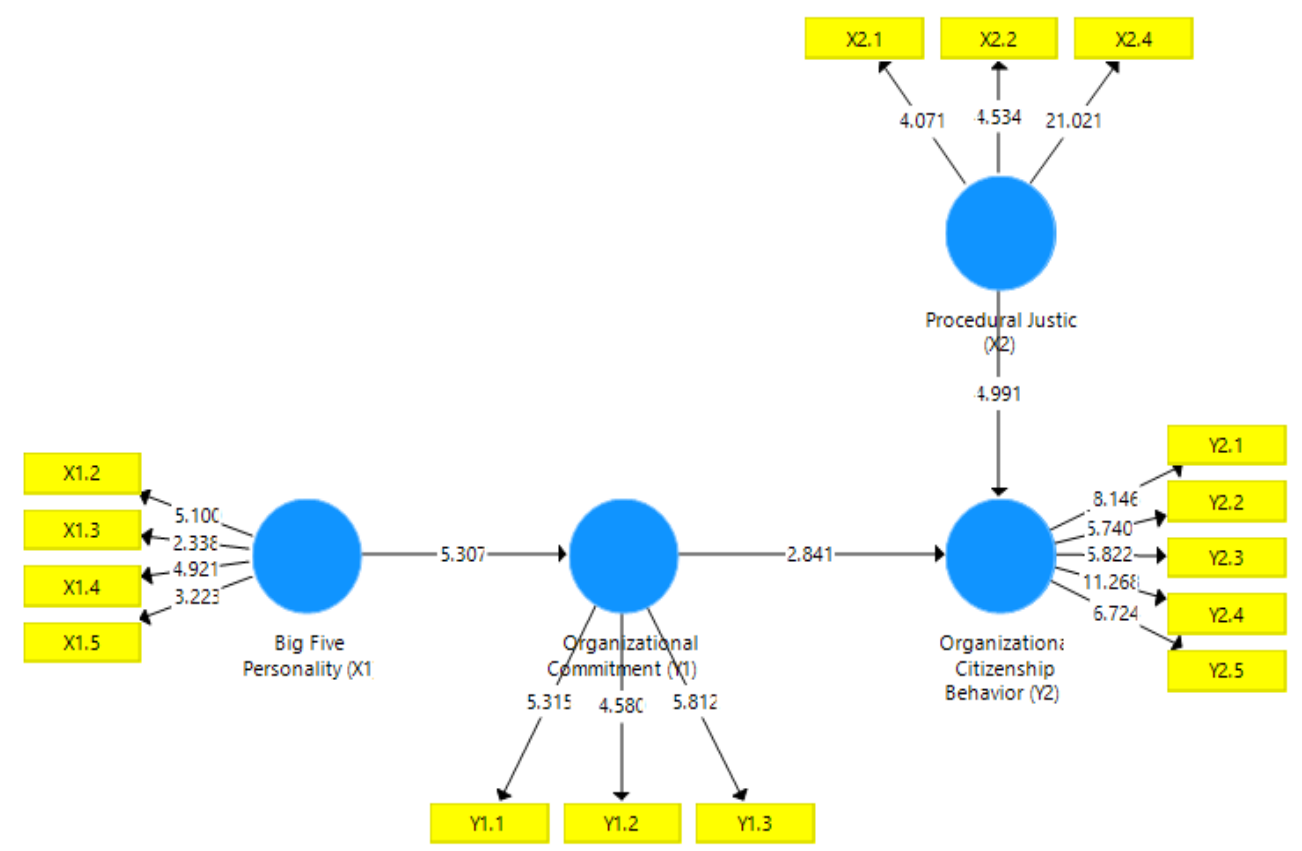

Figure 1 - Output diagram of bootstrapping

The Relationship of Procedural Justice to Organizational Citizenship Behavior has an R-Square value of 0.386 , which means that the Organizational Citizenship Behavior variable that can be explained by Procedural Justice is only $38.6 \%$. The remaining $61.4 \%$ is influenced by other variables which are not examined in this study.

Table 1 - R-Square Values

\begin{tabular}{ccc}
\hline \hline Variables & R-Square & Note \\
\hline \hline Organizational Commitment $(\mathrm{Y} 1)$ & 0,170 & Very weak \\
Organizational Citizenship Behavior (Y2) & 0,386 & Enough \\
\hline
\end{tabular}

Source: PLS 2019 Output.

Hypothesis testing is used to partially test the influence of exogenous $(X)$ and endogenous ( $\mathrm{Y}$ ) variables by looking at coefficients path and comparing t-statistics with ttables. T-value obtained from the bootstrapping with Smart-PLS software. Bootstrapping testing also aims to minimize the problem of research data abnormalities (Ghozali, 2006). The following table shows the Path Coefficient for each variable:

Table 2 - Path Coefficients

\begin{tabular}{cccccc}
\hline \hline Variables & Original Sample (O) & Sample Mean (M) & Standard Error (STERR) & T-Statistic & P-Values \\
\hline $\mathrm{BF}=>$ OC & 0,423 & 0,459 & 0,080 & 5,307 & 0,000 \\
OC $=>$ OCB & 0,312 & 0,313 & 0,110 & 2,841 & 0,005 \\
$\mathrm{PJ}=>$ OCB & 0,476 & 0,488 & 0,095 & 4,991 & 0,000 \\
$\mathrm{BF}=>$ OCB & 0,132 & 0,144 & 0,061 & 2,149 & 0,032 \\
\hline
\end{tabular}

After evaluating the structural model, the following equation results are obtained:

Organizational Citizenship Behavior $(\mathrm{Y} 2)=0.476 \mathrm{X} 1+0.005 \zeta 1$

Organizational Citizenship Behavior $(\mathrm{Y} 2)=0.312 \mathrm{Y} 1+0.423 \mathrm{X} 2+0.032 \zeta 2$

Based on the P-Values value on the relationship between Procedural Justice and Organizational Citizenship Behavior of 0,000 . This proves that Procedural Justice has a significant influence on Organizational Citizenship Behavior because the P-Values value is smaller than 0.050 , so it can be concluded that $\mathrm{H} 1$ is accepted. 
This is reinforced by previous research by Kamdar et All (2006) stating that our findings show not only that individual differences directly predict Organizational Citizenship Behavior role definition but also that they have moderate relationships between procedural justice perceptions and Organizational Citizenship Behavior role definitions.

The personal observation of the researchers regarding this matter, found that some employees of Kutai Kartanegara University who felt that they had enough equality of treatment and justice in their workplace tended to do positive behavior towards their fellow colleagues, this was in line with the statement that Procedural Justice had an influence on Organizational Citizenship Organizational Behavior Citizenship Behavior, as stated by Greenberg (2005) in Wikiantari (2013) that people will be concerned with other people towards the organization where they work when they believe that the organization has treated them fairly. Basically, every individual who lives in the same scope will always try to help each other, because basically human are social beings who are always related to each other in an effort to achieve a common goal.

Thus the synthesis that can be drawn from the discussion above is that Procedural Justice has a significant influence on Organizational Citizenship Behavior. In the second hypothesis testing, it was found that the P-Values on the relationship between Big Five Personality to Organizational Commitment was 0,000. This proves that the Big Five Personality of Kutai Kartanegara University employees has a significant influence on Organizational Commitment, this argument refers to the P-Values which is less than 0.05 , so that the second hypothesis stating that the Big Five Personality affects the Organizational Commitment can be accepted. On personal observation, the researchers found that some respondents were more interested in new things in an effort to find satisfaction and experience, it became a separate reason in meeting the needs of these individuals in the organization that sheltered them. In line with the thoughts of Goldberg1981 in Feist and Jess (2009) who states that "Openness to experience measures the desire to seek and appreciate new experiences, get to know something that is not familiar and has broad interests. Employees at the University of Kutai Kartanegara with Organizational Commitment are influenced by factors to seek and appreciate new experiences.

Thus the synthesis that can be drawn from the discussion above is that Big Five Personality has a significant influence on Organizational Commitment.

On the third hypothesis testing, it was found that the P-Values on the relationship between Organizational Commitment and Organizational Citizenship Behavior was 0.005. This proves that the Organizational Commitment of Kutai Kartanegara University employees has a significant influence on the individual Organizational Citizenship Behavior, this argument refers to the P-Values less than 0.050 , so the third hypothesis stating that Organizational Commitment influences Organizational Citizenship Behavior can be concluded that this argument refers to the P-Values value less than 0.050 , so the third hypothesis stating that Organizational Commitment influences Organizational Citizenship Behavior can be accepted.

This is reinforced by previous research by Prasetio et al (2017) stated that the variable "Organizational Commitment indeed contributes as a mediator in the effect of Job Satisfaction on Organizational Citizenship Behavior."

The personal observation of the researchers regarding to this matter, Researchers found that some employees of Kutai Kartanegara University who had a high level of organizational commitment tended to carry out extra-role of Organizational Citizenship Behavior, this was due to a sense of individual responsibility towards their performance which was clearly tangent to the performance of coworkers as a team, thereby triggering the individual in helping to complete the work of other co-workers. As stated by Gautam, Van Dick, Wagner (2004) that "The commitment of these employees is the driving force in the creation of Organizational Citizenship Behavior in organizations. Organizational commitment is one of the important factors influencing the creation of Organizational Citizenship Behavior in organizations". This view conveyed that employee commitment can trigger extra-role behavior, this need to be mentioned, considering commitment is one of the important factors that influence it. 
Thus the synthesis that can be drawn from the discussions above is that the Organizational Commitment has a significant influence on Organizational Citizenship Behavior.

On the fourth hypothesis testing, it was found that the P-Values on the relationship between Big Five Personality to Organizational Citizenship Behavior through Organizational Commitment was 0.032 . This proves that the behavior of Big Five Personality employees of Kutai Kartanegara University has a significant influence on the Organizational Citizenship Behavior through Organizational Commitment, this argument refers to the P-Values value which is less than 0.050 , so the fourth hypothesis stating that Big Five Personality has a significant influence Organizational Citizenship Behavior through Organizational Commitment is acceptable.

This is reinforced by previous research by Salwa, Wikansari (2017) which states that "Openness is a personality dimension that has a significant relationship to the formation of Organizational Citizenship Behavior for employee of PT. Amarta Karya (Persero) Bekasi. There is a significant correlation between the openness variable of 0.377 with a significance of $0.040<0.05$ on the formation of Organizational Citizenship Behavior for employees of PT Amarta Karya Persero".

Researchers observations related to this matter, researchers found that some employees who have high responsibility for their work tend to be diligent and work hard and are able to complete the tasks given. They also will be more concerned to their colleagues who have not been able to complete their work so that they tends to help their colleagues.

Thus the synthesis that can be drawn from some of the discussions above is Big Five Personality has a significant influence on Organizational Citizenship Behavior through Organizational Commitment.

\section{CONCLUSION AND SUGGESTIONS}

The results of data analysis in the discussion and testing of hypotheses that have been stated previously, so the conclusions of this study are as follows:

Statistically, the view of Procedural Justice of Kutai Kartanegara University employees has a significant effect on the Organizational Citizenship Behavior, in this case, the better the condition of Procedural Justice at Kutai Kartanegara University, the higher the Organizational Citizenship Behavior of its employees. The second finding is that the Big Five Personality of employees at Kutai Kartanegara University has a significant effect on Organizational Commitment. This can be seen from the personality of employees who tend to have a high level of Big Five Personality, it will eventually increase the Organizational Commitment. The third finding is, the Organizational Commitment of employees at Kutai Kartanegara University has a significant effect on Organizational Citizenship Behavior. The higher the level of commitment from the employees of Kutai Kartanegara University, the higher of Organizational Citizenship Behavior. Statistically the Big Five Personality of employees at Kutai Kartanegara University has a significant effect on the Organizational Citizenship Behavior for employees through Organizational Commitment. The higher the Big Five Personality shown by Kutai Kartanegara University employees, the higher the Organizational Citizenship Behavior, which is mediated by employee commitment.

The authorities of Kutai Kartanegara University should pay attention to the application of procedures that apply to their employees. So that complaints about the applicable rules can be minimized and resolved so as to trigger the expected extra-role behavior. The second suggestion, the authorities of Kutai Kartanegara University should pay attention to the behavior patterns of their employees in order to be able to occupy their proper positions, the right work position towards the right individual will further enhance the Organizational Commitment to the expected employee. Third suggestion, the authorities of Kutai Kartanegara University should pay attention to the needs of their employees regarding improvement of their employees' Organizational Commitment, so that the increase in commitment can trigger expected extra-role behavior. The fourth suggestion, authorities at Kutai Kartanegara University pay attention to the behavior patterns of their employees who 
show the personality of the Big Five Personality in order to be strategically positioned, so that other employees will be motivated and trigger the expected extra-role behavior.

Based on the existing literature, we can recommend for future researchers that there are still a variety of theoretical constructs that contribute in creating the Organizational Citizenship Behavior of employees, including Job Satisfaction, Salary Satisfaction and Motivation.

\section{REFERENCES}

1. Allen, N. J., and Meyer, J. P. (1990). The Measurement and Antecedents of Affective, Continuance, and Normative Commitment to the Organization. Journal of Occupational Psychology, 1-18.

2. Bienstock et al. 2003. Organizational Citizenship Behavior and Service Quality.Journal Citizenship Behavior and Service Quality. Journal of Service Marketing. Volume 17 Nomor 4, 357-378.

3. Ghozali and Latan, 2015. Partial Least Squares: Konsep, Teknik and Aplikasi Menggunakan Program SmartPLS 3.0 (Untuk Penelitian Empiris) Edisi 2. Semarang: Badan Penerbit Universitas Diponegoro.

4. Henle, 2005. Predicting workplace deviance from the interaction between organizational justice and personality. Journal of Managerial Issues, volume 17 Nomor 2, 247-263.

5. Ivancevich, Konopaske and Mattison. 2006. Perilaku and Manajemen Organisasi Jilid 1. Jakarta: Erlangga.

6. Kamdar et all, 2006. "All in a Day's Work": How Follower Individual Differences and Justice Perceptions Predict Organizational Citizenship Behavior Role Definitions and Behavior. Journal of Applied Psychology Vol. 91 No.4, 841-855.

7. Mauna and Shabur. 2017. Big Five Personality Terhadap Komitmen Organisasi Dosen Universitas Negeri Jakarta. Jurnal Penelitian and Pengukuran Psikologi. Volume 6 Nomor 1.

8. Organ. 2006. Organizational Citizenship Behavior; its Nature, Antecedents, and Consequences. London: Sage.

9. Prasetio AP et all, 2017. Job Satisfaction, Organizational Commitment, and Organizational Citizenship Behaviour in State-owned Banking. Universal Journal of Management 5 (1), 32-38.

10. Salwa, Wikansari, 2017. Hubungan Kepribadian Big Five Terhadap Pembentukan Organizational Citizenship Behaviour (OCB) Pegawai Pada PT Amarta Karya (Persero) Bekasi. Jurnal IImiah Manajemen \& Bisnis Vol. 18 No.2, 164-176.

11. Wikantari, 2014. Pengaruh Faktor-Faktor Personality and Procedural Justice Terhadap Organizational Citizenship Behavior. Jurnal STIAMI Vol.11 No.2.

12. Wikiantari. 2013. Pengaruh Faktor-Faktor Personality and Procedural Justice Terhadap Organizational Citizenship Behavior. Jurnal Bijak. Volume 11 Nomor 2.

13. Feist and Jess. 2009. Theories of Personality,Seventh Edition. New York: McGraw Hill

14. Gautam, Van Dick, Wagner. 2004. Organizational Identification and Organizational commitment: Distinct aspects of two related concepts. Asian Journal of Social Psychology, 8(3), 305-314. https://doi.org/10.1111/j.1467-839X.2005.00172.x. 